\title{
Research
}

\section{A Wall out of Place: a Hydrological and Sociocultural Analysis of Physical Changes to the Lakeshore of Como, Italy}

\author{
Sarah Laborde $^{1,2}$, Jorg Imberger $^{1}$, and Sandy Toussaint ${ }^{2,3}$
}

\begin{abstract}
The construction of a flood protection structure that obscured views of the lake in Como, northern Italy, led to unprecedented public protest in 2009-2010 and to the eventual dismantlement of the structure. This provided a focus to investigate the delicate interplay of technical and cultural matters in environmental policy-in this case, catchment management and flood prevention. This article shows how a focus on hydrological control in isolation from the rest of the catchment and from the sociocultural context contributed to the project's failure. A key message of the article is that data and analyses from the environmental and social sciences are both pivotal to environmental planning, as they inform different yet interdependent components of a single project. There is value in integrating technical and sociocultural knowledge, both at the academic level, as illustrated by the mixed methods used in this article, and at the policy level, through management frameworks that emphasize cross-sectoral learning and public participation. The analysis also reveals that the notion of "place" has a central role to play in this process of integration, both as a conceptual bridge between technical and sociocultural components of environmental studies and as an emphasis in environmental planning activities to foster the interest and engagement of communities.
\end{abstract}

Key Words: cross-disciplinary science; flood mitigation; Italy; lake catchment governance; place attachment; social movement; technocratic planning

\section{INTRODUCTION}

This paper is a reflection on the integration of technical and cultural components of environmental management. It is based on an empirical analysis of a failed flood-defense project-a structural intervention on the lakeshore of the Italian city of Como (84,085 inhabitants; Italian National Statistical Institute (Istat) 2009) that was opposed by the local population during its construction and subsequently dismantled.

The lakeshore of Como is a line of encounter between the city and Lake Como, a large subalpine lake (Fig. 1). As such, it is physically shaped by the hydrology of the lake catchment and it also constitutes an anthropological place in the sense defined by Augé (1992), because it is relevant to the contemporary lives and identities of the citizens of Como, and it is charged with historical and social meanings (e.g., Turati and Gentile 1858). The transformation of the lakeshore of Como through the construction of a flood-defense structure combined hydrological issues - related to the dynamics of the lake and its impacts on the city through the occurrence of floods-and sociocultural issues related to the relevance of the lakeshore as a meaningful place.

\section{Definitions and Theoretical Framework}

At the societal level, water systems such as lake catchments are broadly conceptualized as a natural resource to be studied, modeled, and controlled by experts in order to support societal uses, including water supply, navigation, and flood mitigation (e.g., Lynch 2010: preface). This approach is grounded in the fields of economics and engineering, and has been labeled as "technocratic" because of its historical reliance on expert judgments and top-down procedures (Fischer 2000).

Meanwhile, at the individual and community levels, people have developed knowledge, practices, and values pertaining to their local environments by living and dwelling in them (Ingold 2000). Meanings related to particular locations emerge from this process, particularly in relation to water places (Strang 2004,Toussaint 2008). Place-based meanings may evolve into attachment (Altman et al. 1992) and play a significant role in one's sense of self and sense of community (Twigger-Ross and Uzzell 1996, Milton 2005). In this paper, we use the concept of "place" to embody the range of meanings and emotions held by individuals or communities for a particular location: it is an explicitly cultural concept, grounded in local human experience (Tuan 1977, Gieryn 2000, Stedman 2002).

Environmental planning outcomes should meet acceptable balances between these interrelated ways of conceptualizing and relating to water bodies, which have been associated with the notions of "technical" and "cultural" rationalities (Fischer 2000: 87). Decisions that fail to do so, for instance by underrating the sociocultural relevance of environmental places, can lead to conflicts and project failures (DevineWright 2009, Devine-Wright and Howes 2010).

Assessing and considering the perspectives of all groups affected by a management decision, including citizens who hold meanings for a particular place (thereby "stakeholders" of any decision affecting that place), have been encouraged

${ }^{1}$ Centre for Water Research, University of Western Australia, ${ }^{2}$ School of Social and Cultural Studies, University of Western Australia, ${ }^{3}$ Centre for Excellence in Natural Resource Management, University of Western Australia 
Fig. 1. Upper left: photograph showing the wall as seen through a window in a wooden fence along the footpath (taken by first author in October 2009). Upper right: map of Lake Como and its catchment. Bottom left: close-up of the city of Como. Bottom right: schematic drawing of the catchment system.

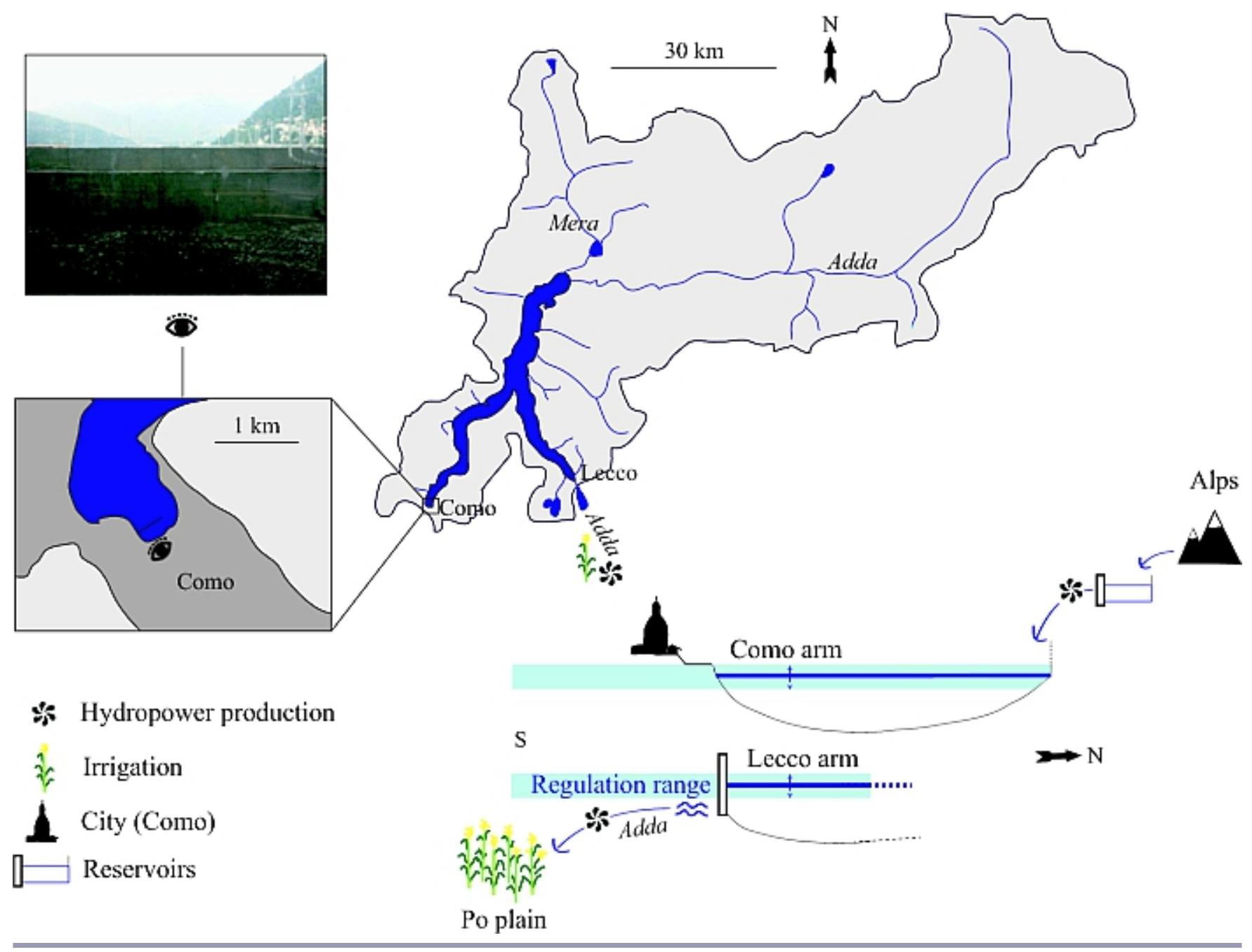

by water management frameworks in the last two to three decades through the implementation of participatory processes under the general framework of "integrated management" (United Nations 1992: Principle 10, European Union (EU) 2000: Article 14, Creighton 2005). Integrated management is based on the consideration of a water catchment in its hydrological and social complexity, in contrast with traditional technocratic approaches that are often based on static designs relying on historical analyses of isolated processes (Pahl-Wostl 2007).

The engagement of local communities has also been identified as a key component of "adaptive management" for water resources and beyond (Pahl-Wostl et al. 2007, Huitema et al. 2009), a complementary approach to integrated management that emphasizes continuous learning and experimentation between and among scientists, managers, and communities in order to better handle the complexity and uncertainty inherent in social-ecological systems (Tompkins and Adger 2004). Within these management frameworks, public participation has been shown to improve relationships among stakeholders, build trust in institutions, and foster the development of environmental knowledge and awareness (Beierle and Konisky 2001, Bijlsma et al. 2011).

The flood management literature echoes the developments in water management outlined above. Scholars and institutions have stressed the value of catchment-integrated approaches (Nunes Correia et al. 1998, EU 2007); adaptive non-structural solutions have been seen as more fair and strategic than major 
engineering works (Vis et al. 2003, Johnson et al. 2007); and public participation has been associated with better decisions and greater chances of policy success (McDaniels et al. 1999).

However, although participatory processes are central to the transition in resources management that is advocated in the academic literature (cf. Pahl-Wostl et al. 2009 for a summary), their practical implementation in the context of environmental planning has proven difficult (Rydin and Pennington 2000). They may be judged as time consuming and costly by decision makers (Irvin and Stansbury 2004), and the public may not trust or be willing to engage in such processes (Barbier 2005). This is especially likely for questions of flood mitigation that are associated with substantial uncertainty and that may still need addressing a long time after the last flood hazard has passed (Godschalk et al. 2003). In Italy, it has been argued that the legacy of a technical, top-down management structure is supported at the individual level by a general lack of interest in engaging with traditional policy, a combination that tends to hinder formal public participation in environmental management (Massarutto et al. 2003).

\section{Aim and Overview of the Article}

Medema and colleagues (2008) expressed the need for more case studies documenting the failures of traditional management practices in the water sector in order to set a stronger case for reforms toward integrated and adaptive management approaches. This article proposes such a case study as it emphasizes aspects of a technocratic approach to flood prevention that have led to policy failure, in particular a focus on hydrological control in isolation from the rest of the catchment and the sociocultural context. Our objectives were also to illustrate the methodological value of integrating insights from technical and social analyses in environmental studies and to show how a focus on the notion of "place" can facilitate such integration.

We use mixed methods across the environmental and social sciences to encompass multiple components of the case study. We start here by presenting hydrological data and analyses to assess the causes and risk of floods in Como and to discuss the engineering rationale behind the project. By way of environmental psychology and anthropology, we then turn to the sociocultural evidence to examine reactions triggered by the structure that became known in Como simply as "the wall" (il muro). This analysis was conducted by triangulating data from quantitative and qualitative sources (Moran-Ellis et al. 2006). Finally, we discuss the relevance of our findings from the practical perspective of environmental planning and management and from a more theoretical standpoint regarding the integration of insights from environmental and social sciences.

\section{FLOODS IN COMO: HYDROLOGICAL CONSIDERATIONS}

\section{Background}

Lake flooding has always been part of the history of Como, as reported in the city archives (Monti 1900), shown in historical prints and engravings (Poggi and Cantù 2000), and depicted physically on the city's facades (Via Volta 54; personal observation 22 Oct 2009). The lake catchment extends north into the Alps, where snow serves as a natural reservoir distributing some of the winter precipitation through spring and summer in the form of snowmelt runoff. The main inflows to Lake Como are partly controlled by a series of 20 upstream alpine reservoirs that were constructed throughout the 20th century and are currently managed by private hydropower companies (Moisello and Vullo 2011); water is retained in spring and summer to be released in autumn and winter when electricity demand is high. The outflow from Lake Como, and hence the lake levels, has been managed since the construction of a dam near Lecco in 1946 for a consortium of downstream water users (Consorzio dell'Adda 2010) with the aim of providing hydropower in winter and irrigation water in summer while moderating lake levels to prevent flooding in Como at one extreme and very low lake levels at the other. (The lake's active storage volume of $254.3 \times 10^{6} \mathrm{~m}^{3}$ (Consorzio dell'Adda 2010).)

Every year since 1975, water levels in the lake have almost reached the city's lowest point of elevation (198.51 m ASLmeasured on the lakeshore by Piazza Cavour in 1997; Comerci et al.2007), although peak levels have been constrained to that limit in most years. However, on 10 occasions the lake caused significant flooding in the city despite regulating activities, flooding an area of more than 1.5 ha. The area susceptible to flooding is composed mainly of parks and commercial interests, and the consequences are mainly impacts on structural integrity (of historical buildings in some cases) and economic losses due to the suspension of activity (M. Gastine, unpublished thesis).

\section{Methods}

In this first section, we provide the hydrological background to the construction of the anti-flood structure on the lakeshore and an overview of the water level changes in Lake Como in response to both long-term and seasonal weather patterns and catchment management. The data used were provided by the Consorzio dell 'Adda. They included daily precipitation at two stations within the catchment (Bormio, north of the catchment [1951-2005], and Olginate, southeast of the lake [19612007]), as well as (1) integrated volumes of weekly storage in the alpine reservoirs upstream of Lake Como [1965-2007]; (2) daily lake outflow since 1946; (3) daily lake surface elevation since 1845 ; and (4) integrated total daily inflows and atmospheric fluxes (direct rainfall and evaporation) since 
Fig. 2. Maximum (red dots), mean (black dots), and minimum (blue dots) annual lake levels since 1845 (original data: Consorzio dell'Adda); and elevation of Piazza Cavour (gray dots, Comerci et al. 2007). Vertical red lines indicate the positive difference between maximum lake level and elevation of Piazza Cavour (e.g., flooding). The black line on the right represents the regulation range.

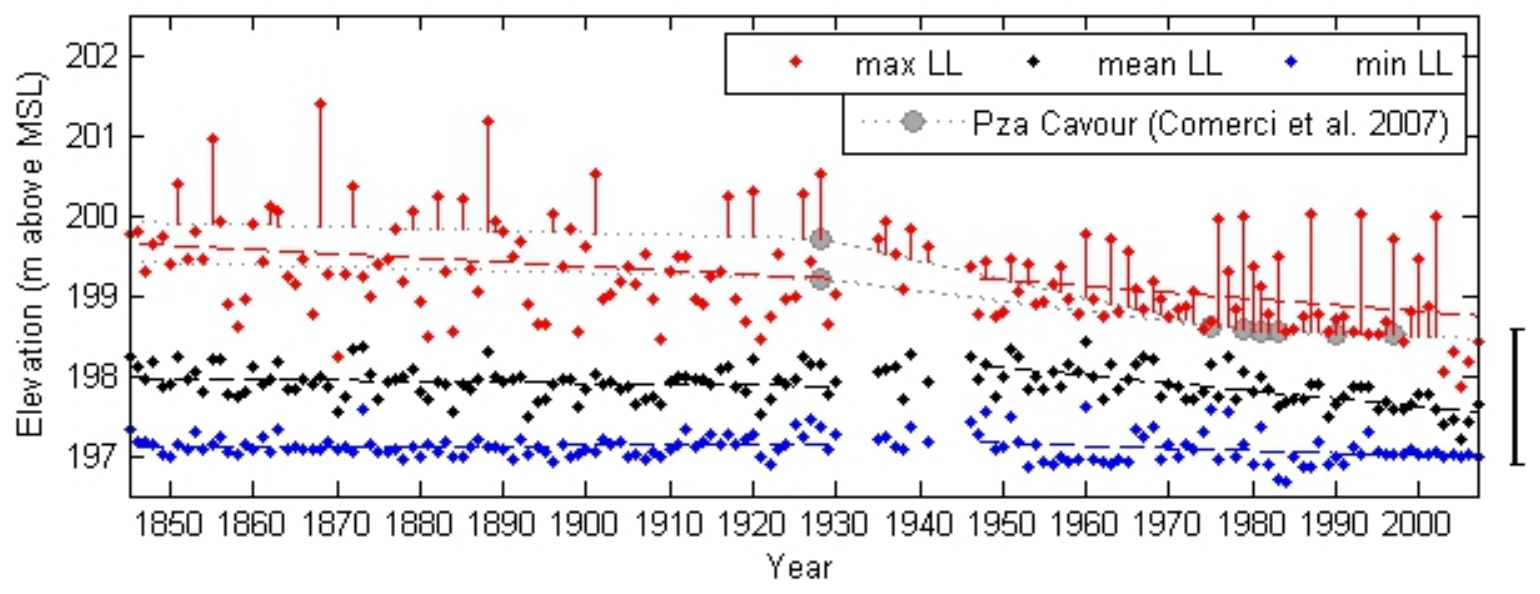

1946, calculated and used daily by the manager from a simple mass balance equation (inflow and atmospheric fluxes = outflow AND lake level variation).

We analyzed annual and seasonal trends of water balance in the catchment based on these data. We also modeled the catchment's water balance using MATLAB, which allowed comparison of management scenarios. The model was a simple water budget relating the lake levels to its total inflows -including atmospheric exchanges and storage in upstream reservoirs - and outflow. Rating curves (Moisello and Vullo 2011) providing the stage discharge relationships at the dam in "regulated open" (all dam gates open) and "natural" conditions (no upstream or downstream dams) allowed modification of the outflow and lake levels in the scenario analysis, whereas the inflows were modified by changing the volumes held in upstream reservoirs. (The reservoirs' total active volume is $514.9 \times 10^{6} \mathrm{~m}^{3}$ (Croce et al. 1987).)

\section{Results}

\section{Long-term trends}

Maximum lake levels have been generally decreasing and visibly restricted by regulating activities since the mid-1980s to an elevation corresponding to that of Piazza Cavour (Fig. 2), with the exception of peak floods (e.g., in 1987, 1993, 1997, 2000, 2002). Minimum lake levels also appear restricted, particularly since the mid-1990s, at a level of $\sim 197 \mathrm{~m}$ above sea level (asl). Mean annual lake levels have been decreasing since the mid-20th century at a rate of $\sim 1 \mathrm{~cm} \mathrm{y}^{-1}$ (Fig. 2). The elevation of the city, and particularly that of Piazza Cavour, has been decreasing through time due to geological subsidence resulting from a combination of natural compaction of the unconsolidated glacial sediments on which the town was built (sinking velocities of $1-2.5 \mathrm{~mm} \mathrm{y}^{-1}$ (Comerci et al. 2007)) and human-induced subsidence (sinking velocities up to $>20 \mathrm{~mm}$ $\mathrm{y}^{-1}$ (Comerci et al. 2007)) following exploitation of the deep aquifer between 1950 and 1975. The current sinking rate, which is expected to continue in the near future, is approximately $2.5 \mathrm{~mm} \mathrm{y}^{-1}$ (Comerci et al. 2007).

The long-term trends affecting flood mitigation in Como can be summarized as follows: (1) subsidence of the city has increased the need for flood mitigation; and (2) the dam control of lake levels has improved through time, increasingly supporting flood mitigation.

\section{Seasonal trends and water uses}

Flooding is most frequent in late spring and early summer (June, July) when snowmelt coincides with high rainfall and in autumn (October) when rainfall events cause the most damaging episodes (Fig. 3). Part of the summer snowmelt runoff is stored upstream in the hydropower reservoirs, which buffer potential runoff peaks by reducing the total discharge to the lake by an average of $29 \mathrm{~m}^{3} \mathrm{~s}^{-1}$ between May and September. During the same period, the lake dam is used to store water and, therefore, maintain high lake levels (Fig. 3) in preparation for the high summer irrigation demand. From late autumn to early spring (October-April), electricity production peaks, and the upstream reservoir releases contribute positively to the discharge into Lake Como by an 
average of $21 \mathrm{~m}^{3} \mathrm{~s}^{-1}$ (see also Consorzio dell'Adda 1990). In October and November, when there is significant risk of flooding due to heavy rains, the contribution of upstream reservoir releases on the lake level averages $0.7 \mathrm{~cm}_{\text {day }}{ }^{-1}$.

Fig. 3. Number of days per month of the year when lake levels were higher than $198.51 \mathrm{~m}$ ASL (corresponding to the lowest point of Piazza Cavour; Comerci et al. 2007) and 199.22 m ASL (corresponding to significant floods with more than 1.5 ha of the city flooded; Gastine 2006, unpublished thesis), averaged over the period (1965-2007).

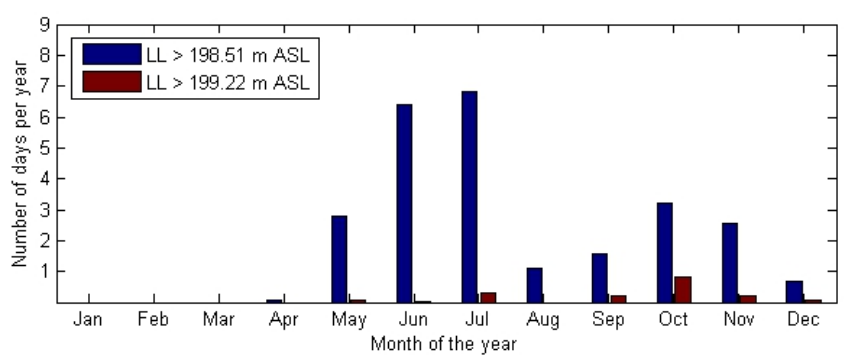

The seasonal trends affecting flood mitigation in Como can be summarized as follows: (1) in late spring, lake storage objectives compete with flood mitigation whereas upstream reservoir storage acts as an inflow buffer and thus supports it; and (2) in autumn, upstream power production objectives compete with flood mitigation.

\section{Extreme events}

Besides the impact of lakeshore subsidence, the high frequency of floods in the late 20th century in Como was associated with heavy rainfall-runoff events that have become increasingly frequent since the 1970s (Fig. 4; see also Brunetti et al. 2001). These episodes are balanced by dry periods causing inflow minima to decrease (Fig. 4B, black line): the runoff to the lake has, therefore, been evolving in the last four decades toward an increased variability (Fig. 4B). Aside from the changing rainfall patterns, a review of recent studies suggests that other important hydrological variables in the region, e.g., the snow:rain ratio and glacier mass balance, are showing nonlinear trends (Horton et al. 2006, Grothmann et al. 2009, Huss et al. 2009).

The following two points can be made about the stochastic component of flood mitigation in Como: (1) heavy rainfall events have become more frequent over the last 30-40 years, increasing the need for flood prevention; and (2) runoff patterns, and the catchment hydrology in general, have become less predictable.

\section{Flood mitigation}

The upstream reservoirs are managed solely to meet hydropower demand variations, whereas downstream dam management takes flood prevention into account: when the lake level approaches the lowest elevation on the lakeshore, the lake manager opens the dam gates (Fig. 5). Dam management has contributed to the decreasing intensity and duration of floods in Como. However, in the case of heavy rainfall, complete opening of the dam gates once the rain starts may not be sufficient to prevent Como from flooding as the maximum outflow is limited (about $900 \mathrm{~m}^{3} \mathrm{~s}^{-1}$ : Fig. 5), and downstream flooding risks must also be considered. The isolated management of the downstream dam is thus not sufficient to prevent all floods and their material impact on the city of Como; especially as extreme rainfall events are becoming more frequent.

Results from a simple model of the catchment water budget illustrate the potential benefits of an integrated upstreamdownstream management for flood mitigation. For the modeling exercise, we considered the flood of November 2002 as an example that was caused by an extreme rainfall event. Starting on 1 January 2002, we compared the measured lake levels with calculated values based on the rating curves in Fig. 5, characterizing "natural" and "open" regimes. Results in Fig. 6 show that the actual lake levels reached during the flood peak in late November 2002 are equivalent to those that would have been reached with all dam gates open from the beginning of the year, and nearly $80 \mathrm{~cm}$ below those that would have been reached in a "natural" catchment (no upstream or downstream dams).

The blue line represents a scenario where the upstream reservoirs act to buffer the flood. We assumed that (1) rainfall over the catchment was homogeneous and the reservoirs could intercept $10 \%$ of the total runoff (Croce et al. 1987: 106); (2) the reservoirs operated as usual unless the water level in Lake Como reached $10 \mathrm{~cm}$ below the lowest level of Piazza Cavour (in that case, they started storing inflow water-calculated as $10 \%$, then $5 \%$ of the total inflow to the lake-until the level was back under the threshold); and (3) when the lake level dropped below $50 \mathrm{~cm}$ under the Piazza, accumulated water was released at a rate corresponding to $20 \%$ of the total daily inflow to the lake. Under this scenario, the peak level in 2002 would have been reduced by about half a meter. Should the reservoirs only intercept $5 \%$ of the runoff to limit their loss in power production, the peak would still have been reduced by about $30 \mathrm{~cm}$.

This scenario was oversimplified, and its results are to be taken with caution as individual data on the runoff and reserved volumes stored within the reservoirs were not available. However, it clearly demonstrates some potential and 
Fig. 4. A) Maximum daily rainfall observed in Bormio for each year between 1951 and 2005 (upper Adda catchment, blue line) and in Olginate between 1961 and 2007 (southeast of the lake, cyan line), and fitted linear trends (data: Consorzio dell'Adda). B) Highest and lowest total lake inflow calculated for the years 1946 to 2007 and fitted linear trends (data: Consorzio dell'Adda; atmospheric fluxes are included).
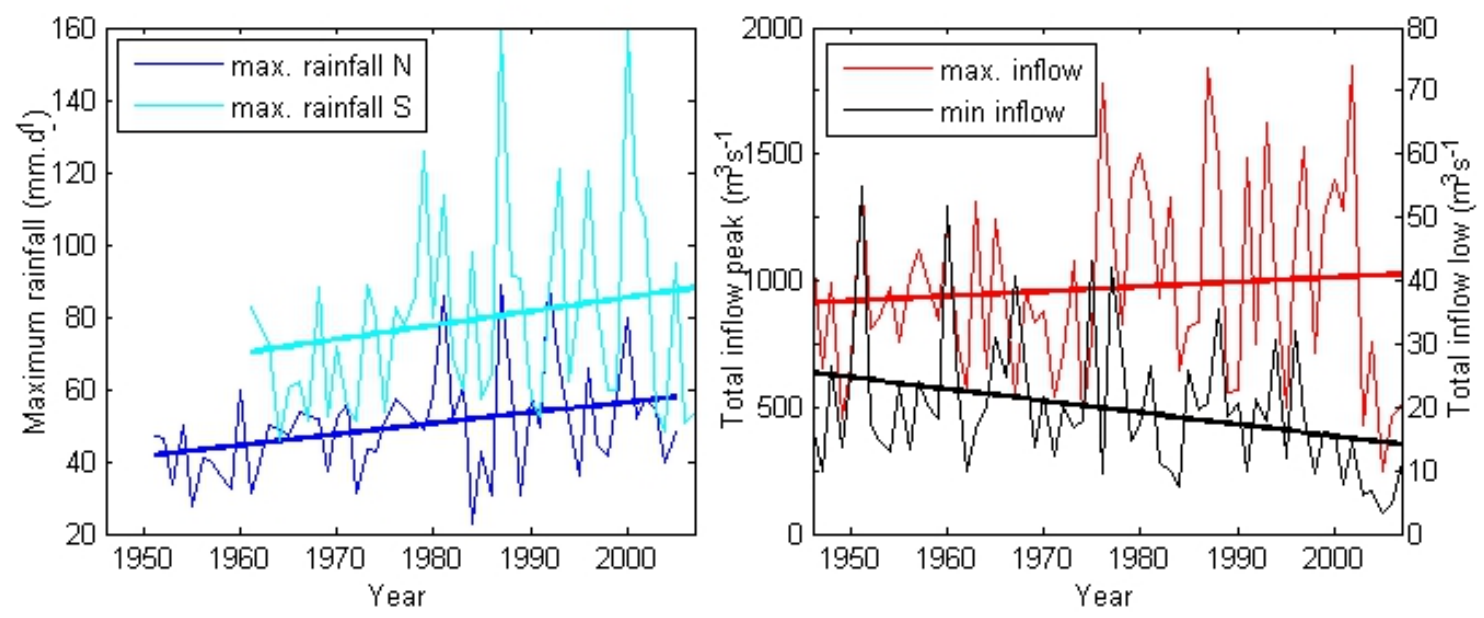

unexplored benefits in coordinating catchment objectives among upstream, downstream, and the lakeshores. Considering that a flood-defense structure was to be built on the lakeshore, its height could have been reduced for the same degree of flood protection if the flood buffering capacity of the upstream reservoirs had been considered.

\section{The Flood Defense Project}

The idea behind the project was based on a general recommendation to re-elevate the subsided city shore as part of a series of combined measures proposed by scholars in the late 1980s to manage flooding in Como (Guariso et al. 1986, Croce et al. 1987). The project plans proposed the construction of an anti-flood structure on the lakeshore composed of both permanent and mobile barriers, at an elevation of $200.3 \mathrm{~m}$ asl corresponding to approximately $1.8 \mathrm{~m}$ above the lowest point on Como's lakeshore square (Piazza Cavour). This elevation, which had never been reached by the lake since its regulation, was based on an historical analysis of lake levels (time series from 1946 to 1990) and the objective of protecting the city from 50-year peak floods.

The decision makers chose a single structure over a combination of "softer" interventions, such as improving the network of gauges on the lake inflows, in part because the latter would only have had partial success in reducing maximum flood levels (Croce et al. 1987). Nor did they take into account the possibility of integrating upstream and downstream catchment management, possibly because of the costs and difficulties of negotiating priorities between public and private institutions at different scales (including transboundary, as two of the upstream hydropower reservoirs are located in Switzerland).
Fig. 5. Daily data of outflow discharge $\left(\mathrm{m}^{3} \mathrm{~s}^{-1}\right)$ plotted against lake level (m ASL) from 1946 to 1990 (light gray) and from 1991 to 2007 (dark gray, covers some light gray data points); dashed black line: rating curve for Lake Como in natural conditions (before construction of the dam in 1946); plain black line: rating curve for Lake Como in regulated conditions, all dam gates open (free regime); dotted red lines: regulation range; plain red line: lowest elevation of Piazza Cavour measured in 1997 (Comerci et al. 2007). Rating curves were elaborated by the Hydrographic Office of the Po River and reported by Moisello and Vullo (2011).

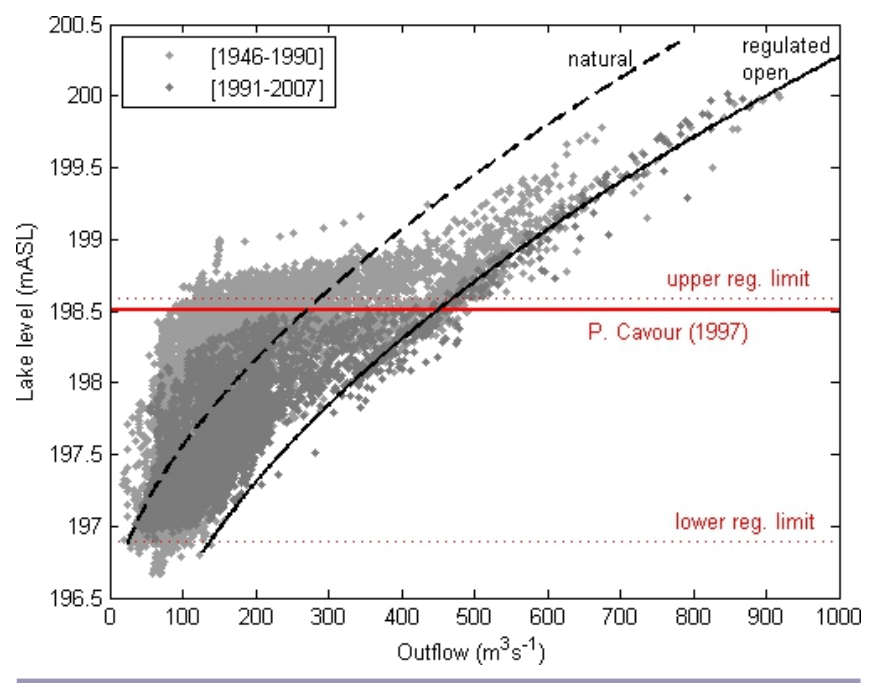


Additionally, a structural intervention benefited from the availability of national and regional funds, which were allocated after flooding in the Valtellina valley north of the lake in July 1987 (law no.102/90), and it offered the opportunity to revamp the city's lakeshore at the same time. These political and financial factors seem to have led to a preference for a single major technical answer to the complex issue of floods in Como, rather than a combination of structural and non-structural approaches at the scale of the catchment.

Fig. 6. A) Lake levels corresponding to different catchment management scenarios for the flood of November 2002. B)

Water volume reserved in the upstream reservoirs in the base case and the management scenario.

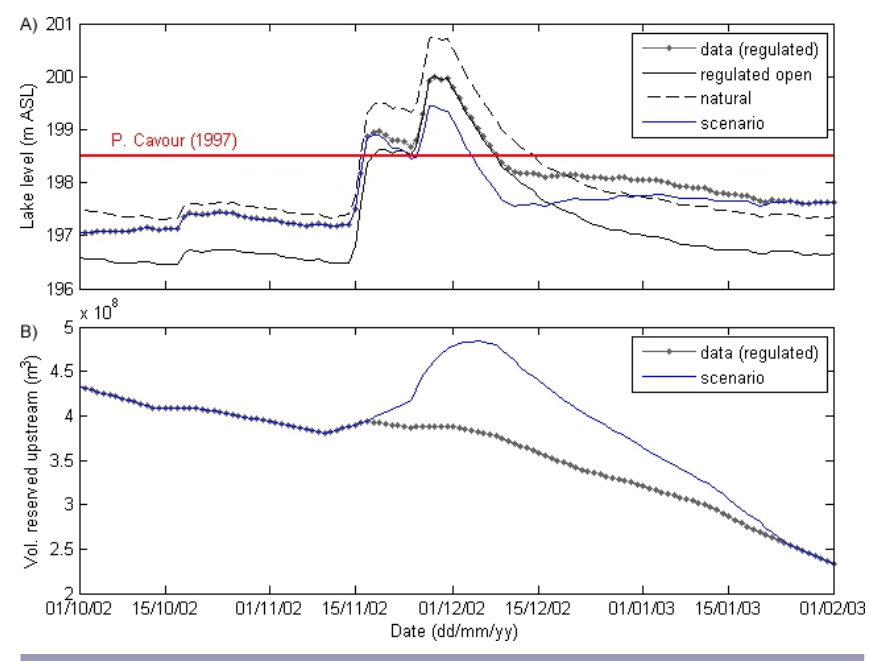

The project was presented to the public in March 2003 with an emphasis on the technology of the mobile barriers, and computer renderings of the revamped lakeshore that did not indicate any obstruction of lake views. The project was received with some skepticism regarding its legitimacy and engineering feasibility, but there was little concern regarding its possible visual impact (La Provincia di Como, thereafter LPDC, 21 October 2003). The original project plans were accessible to the public upon demand, although the project underwent some changes during the implementation stage, which were not publicly communicated.

The construction commenced in January 2008 and proceeded with no major public reaction until mid-September 2009, when a citizen complained about a "wall" (muro) standing on the construction site (Fig. 1, top left) in place of the familiar landscape of the lake (LPDC 23 September 2009). A strong community movement ensued in Como to oppose the structure under construction, fuelled by conversations, Internet exchanges, media reports, and activities that were underpinned by the expression of place-related feelings of loss, frustration, and outrage, as well as doubts related to the legitimacy and transparency of the political and technical authority that had allowed the "wall" to be built. The movement gained momentum in the media, the community, and political spheres, and it was finally dismantled in February 2010.

\section{SOCIAL MOVEMENT AGAINST THE "WALL": A SOCIOCULTURAL ANALYSIS}

\section{Methods}

In this section, we present data concerning people's reactions to the structure when it was under construction. Principles of environmental psychology and anthropology are used to contextualize and analyze the data that were composed of (1) public data: letters from local citizens published in the local newspapers, and a record of the public discussion conducted through a web-based social network between 23 September and 7 October 2009; and (2) responses to an online questionnaire distributed between 4-18 May 2010.

The design of the questionnaire and the choice of the coding frame for the analysis of the public data were supplemented by field notes (FN, hereafter) from informal interviews and observations conducted on site between 1-23 October 2009. This type of multi-method approach is useful for encompassing community responses both in depth and time (Deacon et al. 1999, Moran-Ellis et al. 2006). We start by describing the methods used to collect and analyze the data, then turn to the results. As they complemented each other, qualitative and quantitative results are combined in a single section.

\section{Questionnaire}

The aim of the questionnaire was to collect quantitative data related to the respondents' reactions to the wall. We designed a computerized web-based survey, which was selected for flexibility, time efficiency (de Leeuw et al. 2008), and the general consistency of its results with other survey distribution methods (Gosling et al. 2004). A short article explaining the research objectives and a link to the questionnaire were included in Como's local newspaper La Provincia di Como (the paper version that is sold through the Como province, and the web version that is freely accessible) on 4 May 2010, and the data collection was closed on 18 May 2010. The mode of distribution made the sample a non-random, convenience sample, allowing an examination of internal relationships between variables that made a cultural analysis possible, but was not produced for statistical generalization (Bernard 2006).

Questions relating to political and social themes were based on previous studies that identified a sense of injustice and efficacy as cornerstones of collective action (Mannarini et al. 2009). Place-related questions were based on the framework developed by Scannel and Gifford (2010), from which we selected the items that were most salient in the informal 
interviews conducted in the field (FN, 1-23 October 2009); for instance, the themes of pride and personal history-also reported elsewhere as major components of place attachment in Italy (Carrus et al. 2005). We assessed the reaction to the wall using a set of polar (yes-no) questions regarding a respondent's participation in different protest actions. The other statements were measured by Likert scale-type responses.

A total of 471 entries were analyzed; $57.7 \%$ of respondents were male, $32.1 \%$ female $(11 \%$ did not answer the question about sex); the age distribution differed from that of the citizens of Como and its province mainly by an underrepresentation of people $<17$ and $>55$ years old (demographic data: Istat 2009), which may be explained by the lower interest of the former in daily newspapers, and of the latter in the Internet. Fifty-one percent of respondents were current Como residents when they responded to the questionnaire, of which the great majority (91.4\%) had been living there for more than 10 years. Non-resident respondents were connected to the city and the lake because they had once lived in Como (29.9\%) or they worked in the city $(30.3 \%)$ or in the Province $(31.5 \%)$. Almost half (41.2\%) the respondents reported seeing the lake every day, $28.9 \%$ several times a week, $21.2 \%$ between once a month and once a week, and $8.7 \%$ once a month or less. A total of 208 respondents, $44.2 \%$ of the total, engaged in at least one mode of protest against the wall.

We first undertook a principal component analysis (PCA) with orthogonal rotation to reduce responses to survey questions into a smaller number of variables (de Vaus 2002, Bernard 2006). We then used $t$-tests to assess whether the scores of these composite variables differed significantly between groups of individuals who engaged in different protest activities; and we conducted analyses of variance to explore the significance for these composite variables of other variables such as age, education, and frequency of contact with the lake.

\section{Public data}

In order to compare our data with the PCA results and to identify patterns in time, especially as the questionnaire data was gathered several months after the dismantlement of the wall, we conducted a thematic content analysis on two written data streams of residents' reactions to the wall (Bernard 2006). We examined 225 letters and comments published in the local daily newspaper La Provincia di Como between 23 September and 7 October, which corresponded to the initial peak of concern about the wall. These constituted all items on the topic received by the newspaper during that period, except those that were screened by the newspaper's editorial staff for abusive language and excessive length (LPDC, 25 September to 7 October 2009).

We also analyzed the record of 382 communication items, posted during the same time period, in an online group that had formed on a social networking website as a response to the wall. The group formed on 23 September and grew to about 7000 people by 7 October (up to 8000 later on); 228 people took part in the discussion analyzed (151 males, 73 females, 4 unidentified). This was valuable data for our analysis because (1) it was public, unfiltered, and dated, allowing for a longitudinal study of dominant themes; and (2) this particular web-based group had played a role in the mobilization of the residents against the project and particularly in the organization of public protests. We analyzed all texts with the coding frame summarized in Appendix 1. Quotes from letters and Internet discussions are reported to illustrate various knowledge claims and arguments (Bernard 2006); these were translated into English for the purpose of this article (Appendix 2).

\section{Results}

A social movement grounded in a sense of injustice, community, and place

The PCA results are summarized in Table 1. The first three principal components together explained $51.1 \%$ of the variance. After an orthogonal rotation, we identified three defining themes for these clusters of responses that had internal consistency (Table 1, de Vaus 2002). Questions relating to attachment, personal memories, and pride associated with the lake were grouped in a "lake attachment" variable (vA). Those relating to issues of legitimacy and soundness of the project and transparency of the implementation process referred to the different forms of symbolic, economic, and actual power sustained by different authorities and were, therefore, grouped in a "political discontent" variable (vP). Finally, questions relating to a sense of shared emotion, social unity, and efficacy against the project were grouped in a "social cohesion" variable (vS). The concept of the wall as a threat to the city's economy scored high in the vP and vS factors because the economic argument may be part of a political rationale about the legitimacy of the structure $(\mathrm{vP})$ whereas the word "threat" in the question may have suggested a defensive group response related to vS. It scored higher in "social cohesion" factor and was integrated to the corresponding variable (vS).

We are mindful that the three integrated variables $\mathrm{vA}, \mathrm{vP}$, and vS cannot be considered as scales measuring a single construct. The series of questions that constituted them were designed to capture some of the complexity of the concepts they relate to (like attachment to place; see Scannel and Gifford 2010) and, as a result, their internal consistency values are average (Cronbach's alpha values [0.5-0.7]). With this caution in mind, it is still useful to conduct further analyses with these composite variables computed by integrating the three groups of questions shown in Table 1.

A series of $t$-tests showed that respondents who had engaged in any form of protest against the wall scored significantly higher in the three variables $\mathrm{vA}, \mathrm{vS}$, and $\mathrm{vP}$, than people who 
Table 1. PCA loadings for questionnaire items after rotation (Varimax with Kaiser normalization); questionnaire statements were translated from Italian

\begin{tabular}{|c|c|c|c|}
\hline \multirow{2}{*}{$\begin{array}{l}\text { Questionnaire statements translated from Italian } \\
\text { I am proud of the lake landscape }\end{array}$} & \multicolumn{3}{|c|}{$\begin{array}{l}\text { Component loadings } \\
\text { (orthogonally rotated) }\end{array}$} \\
\hline & .569 & .268 & -.268 \\
\hline The lake reminds me of important moments in my life & .818 & -.082 & .109 \\
\hline I feel attached to the lake & .796 & .134 & .167 \\
\hline The majority of Comaschi was opposed to the wall construction (from September 2009) & .041 & .696 & .035 \\
\hline From the beginning, I trusted in the efficacy of the protest against the wall & .088 & .727 & -.051 \\
\hline The wall would be useful to prevent floods in $\mathrm{Como}^{\dagger}$ & .074 & .216 & .740 \\
\hline The wall is a threat to the economy of Como (tourism) & -.024 & .537 & .452 \\
\hline $\begin{array}{l}\text { The wall would have allowed more water to be tored sin the lake, allowing greater use in the } \\
\text { agricultural districts downstream } \dagger\end{array}$ & .120 & -.089 & .618 \\
\hline $\begin{array}{l}\text { The city administration provided sufficient information on the project before starting the } \\
\text { construction } \dagger\end{array}$ & -.083 & .129 & .632 \\
\hline I was very surprised by the construction of the wall & .129 & .481 & .274 \\
\hline Composite variable & $\mathbf{v A}$ & $\mathbf{v S}$ & $\mathbf{v P}$ \\
\hline Cronbach's alpha & 0.611 & 0.552 & 0.506 \\
\hline
\end{tabular}

did not protest (Table 2). Overall, the political component (vP) of the protest was the most salient in the $t$-test results, particularly for people who engaged in signing petitions and in public demonstrations. People who wrote a letter to the newspapers scored higher in lake attachment (vA), and social cohesion (vS) was particularly relevant to people who signed a petition. The text analysis confirmed the strong political dimension for the protest found in the questionnaire data: political themes were present in $52 \%$ of the letters and $45 \%$ of the items from the online conversation, in particular as a critique of the insufficient and distorted information provided by decision makers to the public. This is expressed, for instance, in the following quote (see also quote 1, Appendix 2):

It is certainly not easy for a regular citizen to have access to a public work project and it is certainly not trivial either to interpret it for those who are not an engineer or architect. What has been fed to us, the ignorant people, were three "rendering" images and on those there was no wall or, and this is very important to highlight, any "significant" lifting of the sidewalk. (Letter published on 25 September 2009.)

Place-related concerns were evident in $69 \%$ of the letters and $21 \%$ of the online comments, reflecting the strong association of vA with letter writing as a form of protest that was found in the questionnaire data. Place attachment was often expressed by the use of the adjective "mio" (mine) or "nostro" (our) followed by "lago" (lake), "lungolago" (lakeshore) or "citta" (city). For example, a woman from Como wrote (see also quotes 2-4):

I want to see my fish again, big, small, sick, fast, slow, they are mine. The clean bottom in winter and the clear waters, dirty in summer, green, opaque, but it is my lake. (Letter published on 28 September 2009.)

Nonparametric bivariate correlations indicated modest but significant correlations in the questionnaire data between vA and vS (Kendall's $\tau=0.154, N=420, p<0.001$ ), between vS and $\mathrm{vP}(\tau=0.178, N=420, p<0.001)$ as well as, to a lesser extent, between vA and vP $(\tau=0.095, N=419, p<0.05)$. These links were apparent in the qualitative data, too. For instance, the political theme of accountability for the situation was prominent in both the letters $(55 \%)$ and online comments (28\%) and was associated with emotional content that often explicitly referred to place-related attachments and concerns about aesthetic and/or cultural values associated with the city, the lake, and/or the lakeshore (e.g., quote 2). In both data sets, local attachment to place was also associated with a social dimension expressed as the sensation of belonging to a community being threatened in one aspect of its identity and continuity by the disruption of a familiar landscape (quotes 57). The following quote illustrates the kind of reaction, commonly found in the analysis, where political discontent, social cohesion and attachment to place were all embedded. By illustrating the correlations found among vA, vP, and vS in the questionnaire responses, it also shows the value of combining quantitative and qualitative data:

Those who have allowed and realized such a disgrace ignoring the history of Como offend the city by injuring it in its peculiar vocation, insult the citizens and humiliate the future generations. (Letter by Como resident published on 25 September 2009.)

The interplay of attachment to place and sense of community also resulted in a form of expectation by some citizens that decision makers born and raised in Como would share and 
Table 2. Differences in vA, vS, and vP scores for different protest groups

\begin{tabular}{|c|c|c|c|c|c|c|c|c|c|}
\hline & & \multicolumn{2}{|c|}{ Any form of protest } & \multicolumn{2}{|c|}{ Letter to newspapers } & \multicolumn{2}{|c|}{ Petition } & \multicolumn{2}{|c|}{ Public demonstration } \\
\hline & & NO & YES & NO & YES & NO & YES & NO & YES \\
\hline vA & $\begin{array}{l}\mathrm{N} \\
\text { Mean } \\
(\mathrm{SD})\end{array}$ & $\begin{array}{c}257 \\
4.22 \\
(0.70)\end{array}$ & $\begin{array}{c}206 \\
4.48 \\
(0.63)\end{array}$ & $\begin{array}{c}389 \\
4.30 \\
(0.69)\end{array}$ & $\begin{array}{c}35 \\
4.68 \\
(0.40)\end{array}$ & $\begin{array}{c}299 \\
4.27 \\
(0.68)\end{array}$ & $\begin{array}{c}125 \\
4.48 \\
(0.67)\end{array}$ & $\begin{array}{c}324 \\
4.28 \\
(0.71)\end{array}$ & $\begin{array}{c}100 \\
4.50 \\
(0.57)\end{array}$ \\
\hline & Sig. (2-tailed) & \multicolumn{2}{|c|}{-4.23} & \multicolumn{2}{|c|}{-4.96} & \multicolumn{2}{|c|}{-2.91} & \multicolumn{2}{|c|}{-3.21} \\
\hline $\mathrm{vS}$ & $\begin{array}{l}\mathrm{N} \\
\text { Mean } \\
(\mathrm{SD})\end{array}$ & $\begin{array}{c}229 \\
3.75 \\
(0.83)\end{array}$ & $\begin{array}{c}195 \\
4.08 \\
(0.71)\end{array}$ & $\begin{array}{c}353 \\
3.87 \\
(0.81)\end{array}$ & $\begin{array}{c}35 \\
4.16 \\
(0.65)\end{array}$ & $\begin{array}{c}268 \\
3.80 \\
(0.83)\end{array}$ & $\begin{array}{c}120 \\
4.1 \\
(0.68)\end{array}$ & $\begin{array}{c}293 \\
3.86 \\
(0.82)\end{array}$ & $\begin{array}{c}95 \\
4.02 \\
(0.74)\end{array}$ \\
\hline & Sig. (2-tailed) & \multicolumn{2}{|c|}{$\begin{array}{r}-4.31 \\
\mathbf{. 0 0 0}\end{array}$} & \multicolumn{2}{|c|}{$\begin{array}{r}-2.42 \\
\mathbf{. 0 2 0}\end{array}$} & \multicolumn{2}{|c|}{$\begin{array}{r}-3.88 \\
\mathbf{. 0 0 0}\end{array}$} & \multicolumn{2}{|c|}{$\begin{array}{c}-1.69 \\
.091 \text { (n.s.) }\end{array}$} \\
\hline \multirow[t]{2}{*}{$\mathrm{vP}$} & $\begin{array}{l}\mathrm{N} \\
\text { Mean } \\
(\mathrm{SD})\end{array}$ & $\begin{array}{c}228 \\
3.92 \\
(0.80)\end{array}$ & $\begin{array}{c}194 \\
4.32 \\
(0.67)\end{array}$ & $\begin{array}{c}351 \\
4.09 \\
(0.78)\end{array}$ & $\begin{array}{c}35 \\
4.37 \\
(0.65)\end{array}$ & $\begin{array}{c}267 \\
4.00 \\
(0.78)\end{array}$ & $\begin{array}{c}119 \\
4.36 \\
(0.71)\end{array}$ & $\begin{array}{c}291 \\
4.02 \\
(0.81)\end{array}$ & $\begin{array}{c}95 \\
4.39 \\
(0.60)\end{array}$ \\
\hline & $\begin{array}{l}\mathrm{t} \\
\text { Sig. (2-tailed) }\end{array}$ & \multicolumn{2}{|c|}{-5.49} & \multicolumn{2}{|c|}{-2.09} & \multicolumn{2}{|c|}{-4.32} & \multicolumn{2}{|c|}{-4.84} \\
\hline
\end{tabular}

Note: vA, vS, and vP are not normally distributed. The sample size is sufficiently large for the Central Limit Theorem to hold. We conducted nonparametric Mann-Whitney tests that highlighted the same significant differences with equivalent significance levels.

bear their own entrenched feelings for a place that meant much to them and act accordingly, as the following quote suggests (see also quote 8): "I would never have thought that persons born in Como could have allowed such a disaster" (letter published on 25 September 2009).

"The rise of a wall that unites the people" (extracted from a citizen's letter published on 30 September 2009): place-related emotion and engagement

Analyses of variance of questionnaire responses revealed that respondents' sex and level of education had no significant effect on their scores in any of the three variables $\mathrm{vA}, \mathrm{vP}$, and $\mathrm{vS}$. Their age had a significant effect on $\mathrm{vP}$ only $(\mathrm{F}(3)=4.607$, $p<0.01$ ), with post-hoc Tukey's HSD tests showing that people aged 35-54 and >55 years old scored significantly higher in vP than those aged 18-24 years old at the 0.01 level of significance (other differences were not significant). The frequency of contact with the lake (from less than once a month to every day) had a significant effect on vA $(\mathrm{F}(3)=4.9, p<$ 0.01 ) but not on vS or vP. A series of $t$-tests showed, in turn, that people who reported engaging in various activities on the lakeshore (see Table 3) scored significantly higher in lake attachment (vA), but not in political discontent (vP) or social cohesion (vS), than those who did not (Table 3). Beyond local attachments to the lake and the city, references to the aesthetic dimension of the landscape and its moral implications brought international coverage to the case, both via the media and social networks. This aspect, corresponding to the "physical place" component of Scannell and Gifford's framework (2010) was not directly explored through the questionnaire but appeared in $32 \%$ of letters and $9 \%$ of online comments (quotes 23-24). One person spoke, for instance, in the name of "all those who love, not only Como and its lake, but the beautiful in general" (letter published on 26 September 2009).

For Como residents, attachment to the city itself and the perception that the lake is inseparable from it were associated with higher vA scores (respectively $\mathrm{F}(4)=9.52, p<0.001$, and $\mathrm{F}(4)=8.60, p<0.001)$ as well as higher vS scores (respectively $\mathrm{F}(4)=3.40, p<0.05$, and $\mathrm{F}(4)=4.43, p<0.01$ ) (see corresponding quotes 9-12); there was also a significant effect of the length of residence of Comaschi respondents on their attachment to the lake $(\mathrm{F}(4)=2.69, p<0.05$; see also Lewicka 2011).

Many respondents (39.5\%) reported that they had actively informed themselves about the project before the media outbreak of "the wall" (of which, 51.6\% subsequently took part in the protest movement). This early proactive behavior (at least reported as such) was significantly correlated with lake attachment score vA $(\tau=0.107, N=414, p<0.01)$, but not with $\mathrm{vS}$ or $\mathrm{vP}$. The majority of respondents did not actively seek information before they heard or read about the wall, a 
Table 3. Differences in vA, vS, and vP scores for different groups of lakeshore users

\begin{tabular}{|c|c|c|c|c|c|c|c|}
\hline & & \multicolumn{6}{|c|}{ Lakeshore activities } \\
\hline & & \multicolumn{2}{|c|}{$\begin{array}{l}\text { Socializing with family and } \\
\text { friends }\end{array}$} & \multicolumn{2}{|c|}{ Practicing sports } & \multicolumn{2}{|c|}{ Thinking and reflecting } \\
\hline & & NO & YES & NO & YES & NO & YES \\
\hline \multirow[t]{5}{*}{ vA } & $\mathrm{N}$ & 241 & 222 & 351 & 112 & 212 & 251 \\
\hline & Mean & 4.24 & 4.43 & 4.27 & 4.54 & 4.18 & 4.46 \\
\hline & (SD) & $(0.78)$ & $(0.54)$ & $(0.73)$ & $(0.43)$ & $(0.78)$ & $(0.56)$ \\
\hline & $\mathrm{t}$ & \multicolumn{2}{|c|}{-3.07} & \multicolumn{2}{|c|}{-4.77} & \multicolumn{2}{|c|}{-4.31} \\
\hline & Sig. (2-tailed) & \multicolumn{2}{|c|}{.002} & \multicolumn{2}{|c|}{.000} & \multicolumn{2}{|c|}{.000} \\
\hline \multirow[t]{5}{*}{$\mathrm{vS}$} & $\mathrm{N}$ & 215 & 209 & 313 & 109 & 182 & 242 \\
\hline & Mean & 3.91 & 3.89 & 3.88 & 3.96 & 3.87 & 3.92 \\
\hline & (SD) & $(0.81)$ & $(0.78)$ & $(0.81)$ & $(0.75)$ & $(0.84)$ & $(0.76)$ \\
\hline & $\mathrm{t}$ & \multicolumn{2}{|c|}{0.235} & \multicolumn{2}{|c|}{0.193} & \multicolumn{2}{|c|}{-0.759} \\
\hline & Sig. (2-tailed) & \multicolumn{2}{|c|}{.659} & \multicolumn{2}{|c|}{.365} & \multicolumn{2}{|c|}{.448} \\
\hline \multirow[t]{5}{*}{$\mathrm{vP}$} & $\mathrm{N}$ & 214 & 208 & 313 & 109 & 182 & 240 \\
\hline & Mean & 4.13 & 4.08 & 4.09 & 4.15 & 4.03 & 4.16 \\
\hline & (SD) & $(0.80)$ & $(0.74)$ & $(0.79)$ & (0.69) & $(0.78)$ & $(0.76)$ \\
\hline & $\mathrm{t}$ & \multicolumn{2}{|c|}{0.614} & \multicolumn{2}{|c|}{0.367} & \multicolumn{2}{|c|}{-1.69} \\
\hline & Sig. (2-tailed) & \multicolumn{2}{|c|}{.499} & \multicolumn{2}{|c|}{.466} & \multicolumn{2}{|c|}{.093} \\
\hline
\end{tabular}

Note: vA, vS, and vP are not normally distributed. The sample size is sufficiently large for the Central Limit Theorem to hold. We conducted nonparametric Mann-Whitney tests that highlighted the same significant differences with equivalent significance levels.

detachment pre-project implementation that was also revealed in the qualitative data (expressed in $11 \%$ of the letters and $5 \%$ of items from the online discussion). The following quote illustrates this phenomenon of initial disengagement despite, in this case, the belief that the project was illegitimate. It is related here to the idea of political compromise and rather low expectations of local planning policy (see Gambetta and Origgi 2009):

The flood protection structures are useless, and it is not too late to say so. All those who live near the lake know very well that when the lake floods it comes out through the manholes, the garages, the elevator shafts. There is not, and there will never be, a barrier able to stop the lake, as it has been so for two thousand years. So many of us voted for [the mayor] because of the political coalition, holding our noses about this project because we were thinking of the new lakeshore promenade. (Letter published on 5 October 2009.)

The disengagement between citizens and decision makers went both ways, as illustrated by a political actor in the affair who, as the protest was gaining momentum, commented that "citizens should worry about the walls of their own houses" (LPDC, 20 October 2010). As a result of such detachment, neither the desirability nor the scientific grounds for the project were thoroughly discussed before it started and were thus not clear for some citizens, who challenged them a posteriori. Although direct references to the frequency of floods and lakelevel dynamics were few (2.5\% of all documents), some advanced hydrological arguments to suggest that the scale of the project was excessive compared with what they described as a real, but relatively minor, issue of floods in Como (e.g., quotes 13-15 highlighting the recent improvements in the dam management and their mitigating effect on flooding, as seen in the first part of this article). Others disputed the economical (quote 16) and cultural (quotes 17-19) legitimacy of the structure with, at one extreme, a member of the Internet group who emphasized the historical and cultural dimension of floods to oppose all kinds of protective intervention on the shore: "the lakeshore had to be left the way it was-the floods are part of the history of our city" (comment posted on 25 September 2009, accessed on 14 April 2010).

As a result, the structure being built triggered expressions of emotion in the form of surprise, but also outrage, sadness, and/ or shame (see quotes $2 ; 20-22$ ), which were found in $39 \%$ of the letters and $36 \%$ of the online items, mainly in the first few days of the reaction to the wall (Fig. 7, red markers and trend). This confirmed impressions of a strong emotional dimension for the movement gathered on site during the first days of the protest (FN, 9, 16, and 18 October 2009). The frequencies of expression of the different themes in time (Fig. 7) suggest that emotions related to the loss of the familiar landscape (Fig. 7, 
Fig. 7. Theme frequency plot for online discussion platform. Horizontal axis is the item number; items were plotted in chronological order (intervals within gray lines represent 1 day), vertical axis is the count frequency for each theme (moving average over 30 items centered on item i). Lines are best-fit linear trends for different themes. Vertical gray line represents 1 day.

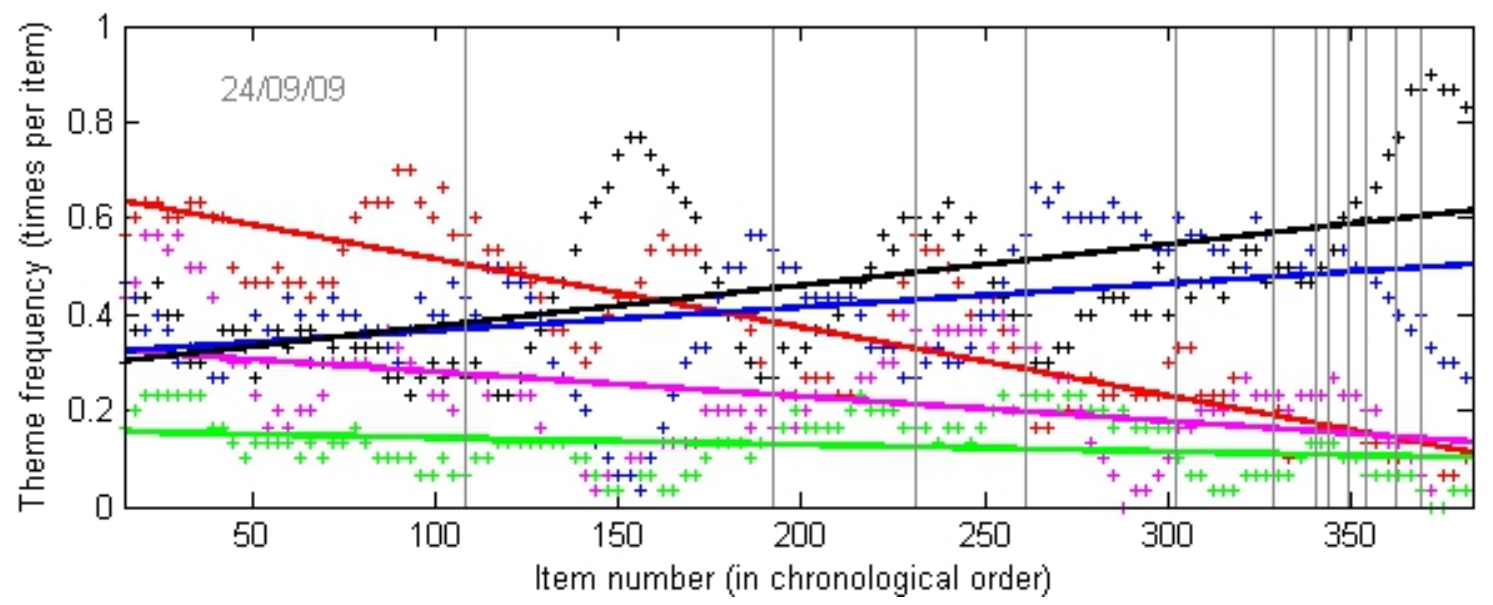

red and magenta trends) were particularly present at the start of the protest movement and may have acted as a trigger. Political and technical arguments against the structure during construction increased with time to foster the protest, as people became more informed about the project (Fig. 7, black trend). The newspaper articles showed similar thematic patterns, from the "shock" (letter published on 25 September 2009) of the loss of the landscape and the relevance of the lake, to questions about the technical and political legitimacy of the project and the use of public money.

\section{Limitations of the Analysis}

The case prompted several other lines of inquiry that we were unable to address given the available resources and the timing of our research. In particular, the specificities of the project variants and the political/financial dimensions before and during its implementation were admittedly important elements of the story from a planning perspective, but were not within the scope of this paper. These latter aspects are embedded in the broader concept of the public's political discontent regarding the project implementation, which we address without entering into any technical detail.

Another limitation of the sociocultural analysis was the data range that extended mainly within respondents with a strong opinion against the wall. Only three textual items (out of 623) did not explicitly oppose the structure as it was being built on the lakeshore. Only $8.1 \%$ of questionnaire respondents declared certain indifference or a positive attitude toward the construction. Although this assessment confirmed an impression of quasi-unanimity against the wall gathered from the 3 weeks of field work (FN, 1-23 October 2009), we are mindful that our data streams are likely to be biased toward "anti-wall" protesters and activists because (1) the local newspaper La Provincia took a strong position early on and played a significant role in focusing on, relaying information about, and extending the protest (FN, 16 and 20 October 2009); (2) the sample of questionnaire respondents was also strongly affiliated with the newspaper through the distribution method (89.2\% of respondents to the questionnaire had read about the story of the wall in the local newspaper); and (3) the online group was explicitly created to focus the protest. Our study did not therefore allow, and was not designed, for a statistical generalization. It was however relevant to explore the nature of the protest against the structure in construction, especially as it was eventually dismantled.

\section{DISCUSSION}

\section{A Case for Integrated and Adaptive Catchment Management}

The analysis identified two interrelated issues with the planning approach that led to the failure of the flood defense intervention in Como. It was shown to be a fragmented approach, both:

- hydrologically: the project design did not account for potential flood-prevention benefit of other possible water management measures in the catchment; and

- socially: a two-way disconnect between decision makers and citizens appeared to be an important cause of the policy failure.

The reasons that led to the choice of a single major structure over a combination of measures for flood prevention appeared to be political rather than scientific. In particular, a funding 
opportunity for the project and the chance to combine it with the renovation of the lakeshore promenade. Embedding flood prevention policy into a catchment management plan would, on the other hand, require rather complex and costly reforms, especially as the upstream reservoirs are controlled by private companies and some of them are located in Switzerland.

The social disconnect emphasized in this study was typical of a technocratic approach (Fischer 2000) that is still predominant in Italian environmental management. In this context, public participation is not usually considered relevant by decision makers, and the public is, in response, generally "skeptical and half-hearted" with regard to its possible participation in policy making (Massarutto et al. 2003: 23). In the Como case, there was little communication by decision makers about the project, even during the implementation phase when some modifications were made. There was also a relatively low proactive interest among the public with regard to the project, which to some extent reflects a cultural attitude (Massarutto et al. 2003, Enserink et al. 2007), but was also due to the technical nature of the available information and thus the lack of opportunity to develop and express informed opinions about it (see Fischer 2000, Barbier 2005).

We argue that, from a long-term perspective, an integrated and adaptive approach to the management of the Adda catchment is required to address the issues highlighted in this study. From a hydrological perspective, a combination of multiple, flexible measures (possibly including structural ones) would be a more desirable option than isolated interventions for the issue of floods in Como and for the management of the catchment in general (see also Guariso et al. 1986, Gandolfi et al. 2007). This is especially true considering the uncertainty associated with the catchment's near-future hydrology, which calls for coordination across multiple scales and sectors of activity (Grothmann et al. 2009). For decision makers in Como, this requires a transition from a "flood defense" policy focused on local control to a "flood management" approach focused on catchment-wide learning (see Johnson et al. 2007: Table 1).

From a social perspective, the focus on learning of integrated and adaptive management approaches would also be likely to improve communication and understanding between decision makers and citizens (Beierle and Konisky 2001, Goldstein 2009). Participatory processes have been shown to enhance the knowledge base of: (a) citizens (Huitema et al. 2010), which, in the case of floods in Como, could have resulted in an early response to concerns such as those expressed in quotes 12-16; and (b) experts and decision makers (Bijlsma et al. 2011), at least with regard to the perceptions and values of citizens (Huitema et al. 2010). In the case of Como, it is hard to imagine that the upheaval of the wall could have happened had there been a genuine and ongoing interaction between citizens and decision makers. The structure might have been altogether different and more in agreement with citizens' values, or the same structure might have been completed, provided citizens were confident about the temporary nature of the wall and its impacts on lake views and that they were satisfied with the prospective of the finished project.

The legislative framework for integrated catchment management in Italy has been in place since 1989, and scientists have demonstrated interest and capabilities for its development in the Adda catchment (Gandolfi et al. 2007). With respect to public participation in policy making, it has been argued that, in Italy, "horizontal" and informal participation is more efficient than structured and hierarchical participation (Massarutto et al. 2003: 24-25). In any case, there is a need to bring decision makers and stakeholders (including citizens) together so that they can learn about each other's perspectives (McLain and Lee 1996, Lebel et al. 2010). Below, we suggest that a focus on place meanings may facilitate the engagement of citizens in such process.

\section{Engaging the Public around Place Attachments and Meanings}

Emotions are pervasive in the relationships people have with their local environments (see also Mitchell et al. 1993), and these can be pivotal when it comes to environmental planning: able, for instance, to trigger a social movement (see also Heatherington 2005, Devine-Wright 2009, and Mannarini et al. 2009). The defense of one's identity plays an important role in the emergence of social movements (Poletta and Jasper 2001), and this is true for place-defense movements. As summarized by Stedman (2002: 577), "we are willing to fight for places that are central to our identities."

This was also the case in Como as the analysis showed. Most questionnaire respondents declared they had not been proactive about seeking information about the project, which is considered relatively normal in a technocratic framework where policy is delegated to experts (Massarutto et al. 2003). Qualitative accounts also reported that citizens had taken relatively little notice of previous failures or suboptimal planning policies. For the wall, however, the mobilization was exceptional, although reactive and oppositional, largely because the lakeshore was a particularly meaningful place for people.

The question now is: are we willing to engage in decision processes for places that are central to our identities?

Preliminary insights from our results suggest that such is the case in Como. We already showed that respondents who had sought information about the project before the media outburst were those with the strongest attachment to the lake. Complementary $t$-tests showed that respondents who attended the city council meetings on the topic of the flood-defense structure or followed them on a local television channel (the council room had limited space for public attendance) also scored significantly higher in attachment to the lake than those 
who did not $(t=-2.322 ; p<0.05)$, although they did not score higher in social cohesion $(t=-1.378 ;$ n.s. $)$ or political discontent ( $t=-1.740$; n.s.).

Attachment to the lake was itself enhanced by physical proximity, frequency of contact, and engagement with it through various activities. People's engagement in the protest in turn fostered their willingness to further protect and enhance the lakeshore: more than 3 months after the dismantlement of the wall, $66.7 \%$ of people who responded to the questionnaire declared feeling more engaged with the planning and conservation of the lake than before the affair had taken place. This was especially true for people who had participated in protest actions $(t=-4.031 ; p<0.001)$.

We suggest that the articulation and analysis of attachments to place have the potential to enhance public participation in policy making and to address the type of disjuncture between local politics and citizens that was observed in Como (see also Cheng et al. 2003, Davenport and Anderson 2005, Manzo and Perkins 2006). Indeed, the protest was a form of participation in planning policy focused on "place," although reactive (see also Devine-Wright 2009). More studies are needed to evaluate the potential of place attachment in enhancing public participation at the early stages of planning processes and to better understand the relationship between place attachment and social cohesion in the context of public participation in local planning policy (Lewicka 2011).

\section{CONCLUSION}

\section{Place-based Integration of Technical and Sociocultural Knowledge}

This study showed how insights from both the environmental and social sciences are pivotal to environmental planning, as they inform different yet interdependent components of a single project. Analyses distilling human perceptions and emotions should thus be integrated to the insights of environmental sciences in a way that is accessible to planners (Manzo and Perkins 2006, Webler and Tuler 2010). Using mixed methods in this study, we first showed that the flood policy failure in Como emerged from an approach to flood management that was hydrologically and socially fragmented, and we argued that this failure constitutes a strong case for the consideration of flood management as embedded in an integrated and adaptive approach to catchment management (as recommended by the EU (2007)). We then showed that forms of attachment for the lake and its city shore played a trigger role in the protest movement against the flood defense structure in construction; and finally, we discussed the potential of such attachments to enhance people's willingness to participate in decision-making processes.

Meanings and attachments related to particular places constitute a form of experiential knowledge of these places, which should be given a more central place in the dialog between the public and decision makers in environmental management. The articulation of an inclusive and relational environmental policy, concerned with the physical and sociocultural connections that constitute each place, may be fostered through programs that interweave scientific and local knowledge such as those described by Swanson et al. (2008) or Selman et al. (2010) whereby local residents and scholars from the sciences, the humanities, and the arts are brought together to engage collaboratively with local landscapes, in connection with human perceptions and emotions, as well as ecosystem dynamics.

Responses to this article can be read online at: http://www.ecologyandsociety.org/voll7/iss1/art33/ responses/

\section{Acknowledgments:}

We wish to thank Malcolm Hollick, Nick Harney, and Ron Oxburgh for their critical reviews of this article during its development, as well as three anonymous reviewers who provided very constructive comments on previous versions. We are grateful to the Consorzio dell'Adda for providing hydro-meteorological data and to Casper Boon for his technical input with the implementation of the web survey. The support of the newspaper La Provincia di Como was greatly valued as it provided a way to distribute the survey. Finally, we would like to thank all the people in Como who contributed to the study by responding to the questionnaire or discussing the issue in the field. At the time of the study, the first author was a recipient of an IPRS scholarship funded by the Australian government and a living allowance funded partly by the Water Corporation of Western Australia and the University of Western Australia. Any opinions, findings, and conclusions expressed in this material are those of the authors and do not necessarily reflect the views of the individuals or agencies acknowledged.

\section{LITERATURE CITED}

Altman, I. A., and S. M. Low, editors. 1992. Place attachment. Human behavior and environment. Volume 12. Plenum, New York, New York, USA.

Augé, M. 1992. Non-lieux, introduction à une anthropologie de la surmodernité. Le Seuil, Paris, France.

Barbier, R. 2005. Quand le public prend ses distances avec la participation. Natures Sciences Sociétés 13:258-265. http://d x.doi.org/10.1051/nss:2005040

Beierle, T. C., and D. M. Konisky. 2001. What are we gaining from stakeholder involvement? Observations from environmental 
planning in the Great Lakes. Environment and Planning $C$ : Government and Policy 19:515-527 http://dx.doi.org/10.1068/ $\underline{\mathrm{c} 5 \mathrm{~s}}$

Bernard, H. R. 2006. Research methods in anthropology: quantitative and qualitative approaches. Fourth Edition. Altamira Press, Oxford, UK.

Bijlsma, R. M., P. W. G. Bots, H. A. Wolters, and A. Y. Hoekstra. 2011. An empirical analysis of stakeholders' influence on policy development: the role of uncertainty handling. Ecology and Society 16(1): 51. [online] URL: http: //www.ecologyandsociety.org/vol16/iss $1 /$ art51/

Brunetti, M., M. Maugeri, and T. Nanni. 2001. Changes in total precipitations, rainy days and extreme events in northeastern Italy. International Journal of Climatology 21:861-871 http://dx.doi.org/10.1002/joc.660

Carrus, G., M. Bonaiuto, and M. Bonnes. 2005. Environmental concern, regional identity, and support for protected areas in Italy. Environment and Behavior 37:237-257 http://dx.doi.or $\mathrm{g} / 10.1177 / 0013916504269644$

Cheng, A. S., L. E. Kruger, and S. E. Daniels. 2003. 'Place' as an integrating concept in natural resource politics: propositions for a social science research agenda. Society and Natural Resources 16:87-104. http://dx.doi.org/10.1080/0894 $\underline{1920309199}$

Comerci, V., S. Capelletti, A. M. Michetti, S. Rossi, L. Serva, and E. Vittoria. 2007. Land subsidence and late glacial environmental evolution of the Como urban area (northern Italy) Quaternary International 173-174:67-86. http://dx.doi. org/10.1016/j.quaint.2007.06.014

Consorzio dell'Adda 1990. Regolazione del sistema Lago di Como - Fiume Adda - Usi irrigui ed idroelettrici. Consorzio dell' Adda - Milan, Italy.

Consorzio dell' Adda. 2010. Statuto del Consorzio dell'AddaCapo 1 - Scopi e limiti del Consorzio - Art. 1 [online] URL: http://www.addaconsorzio.it/.

Creighton, J. L. 2005. The public participation handbook: making better decisions through citizen involvement. JosseyBass, Wiley, San Francisco, California, USA.

Croce, A., U. Maione, E. Mantovani, U. Messina, and S. Zorzi. 1987. Studio per la soluzione dei problemi conessi con le esondazioni del Lago di Como. Ministero dei lavori pubblici - Magistrato per il Po-Parma, Italy.

Davenport, M. A., and D. H. Anderson. 2005. Getting from sense of place to place-based management: an interpretive investigation of place meanings and perceptions of landscape change Society and Natural Resources 18(7):625-641. http:// dx.doi.org/10.1080/08941920590959613
Deacon, D., M. Pickering, P. Golding, and G. Murdoch. 1999. Researching communications. A practical guide to methods in media and cultural analysis. Oxford University Press, Oxford, UK.

de Leeuw, E. D., J. Hox and D. Dillman, editors. 2008. International handbook of survey methodology. Routledge Academic, Abingdon, UK.

de Vaus, D. A. 2002. Analyzing social science data. Sage Publications, London, UK and Thousand Oaks, California, USA.

Devine-Wright, P. 2009. Rethinking NIMBYism: The role of place attachment and place identity in explaining placeprotective action. Journal of Community and Applied Social Psychology 19 (6):426-441 http://dx.doi.org/10.1002/casp.1004

Devine-Wright, P., and Y. Howes. 2010. Disruption to place attachment and the protection of restorative environments: a wind energy case study. Journal of Environmental Psychology 30 (3):271-280 http://dx.doi.org/10.1016/j.jenvp.2010.01.008

Enserink, B., M. Patel, N. Kranz, and J. Maestu. 2007. Cultural factors as co-determinants of participation in river basin management. Ecology and Society 12(2): 24. [online] URL: http://www.ecologyandsociety.org/vol12/iss2/art24/.

European Union (EU). 2000. Directive 2000/60/EC of the European Parliament and of the Council establishing a framework for the community action in the field of water policy. Official Journal (OJ L 327). [online] URL: http://ec.e uropa.eu/environment/water/water-framework/links/index en. $\underline{\mathrm{htm}}$.

EU. 2007. Directive 2007/60/EC of the European Parliament and of the Council on the assessment and management of flood risks. Official Journal L 288, 06/11/2007 P. 0027 - 0034. [online] URL: http://eurlex.europa.eu/LexUriServ/LexUriServ. do?uri=OJ:L:2007:288:0027:01:EN:HTML.

Fischer, F. 2000. Citizens, experts and the environment: the politics of local knowledge. Duke University Press, Durham, North Carolina, USA.

Gambetta, D., and G. Origgi. 2009. L-worlds-the curious preference for low quality and its norms. Oxford Series of Working Papers in Linguistics 1:23.

Gandolfi, C., R. Soncini Sessa, D. Agostani, A. Castelletti, D. de Rigo, A. Facchi, B. Ortuani, F. Pianosi, M. Rienzner, V. Sachero, L. Tepsich, and E. Weber. 2007. IWRM in the Adda basin, northern Italy, Geophysical Research Abstracts 9.

Gieryn, T. 2000. A space for place in sociology. Annual Review of Sociology 26:463. http://dx.doi.org/10.1146/annurev. soc.26.1.463 
Godschalk, D. R., S. Brody, and R. Burby. 2003. Public participation in natural hazard mitigation policy formation: challenges for comprehensive planning. Journal of Environmental Planning and Management 46(5):733-754. http://dx.doi.org/10.1080/0964056032000138463

Goldstein, B. 2009. Resilience to surprises through communicative planning. Ecology and Society 14(2): 33. [online] URL: http://www.ecologyandsociety.org/vol14/iss $2 /$ art33/.

Gosling, S. D., S. Vazire, S. Srivastava, and O. P. John. 2004. Should we trust web-based studies? American Psychologist 59:93-104 http://dx.doi.org/10.1037/0003-066X.59.2.93

Grothmann, T., D. Nenz, and M. Putz. 2009. Adaptation in vulnerable alpine regions lessons learnt from regional case studies. Pages 96-108 in European Environment Agency, editor. Regional climate change and adaptation: the Alps facing the challenge of changing water resources. EEA technical report no 9/2009, European Environment Agency, Copenhagen. Sweden. [online] URL: http://www.eea.europa. eu/publications/alps-climate-change-and-adaptation-2009.

Guariso, G., S. Rinaldi, and R. Soncini-Sessa. 1986. The management of Lake Como: a multiobjective analysis. Water Resources Research 22:109-120 http://dx.doi.org/10.1029/W $\underline{\mathrm{R} 022 \mathrm{i} 002 \mathrm{p} 00109}$

Heatherington, T. 2005. 'As if someone dear to me had died': intimate landscapes, political subjectivity and the problem of a park in Sardinia. Pages 145-162 in K. Milton and M. Svasek, editors. Mixed emotions - anthropological studies of feeling. Berg Publishers, Oxford, UK.

Horton, P., B. Schaefli, A. Mezghani, B. Hingray, and A. Musy. 2006. Assessment of climate-change impacts on alpine discharge regimes with climate model uncertainty. Hydrological Processes 20:2091-2109 http://dx.doi.org/10.1 002/hyp.6197

Huitema, D., C. Cornelisse, and B. Ottow. 2010. Is the jury still out? Toward greater insight in policy learning in participatory decision processes - the case of Dutch citizens' juries on water management in the Rhine Basin. Ecology and Society 15(1): 16. [online] URL: http://www.ecologyandsociety. org/vol15/iss $1 /$ art16/.

Huitema, D., E. Mostert, W. Egas, S. Moellenkamp, C. PahlWostl, and R. Yalcin. 2009. Adaptive water governance: assessing the institutional prescriptions of adaptive (co-) management from a governance perspective and defining a research agenda. Ecology and Society 14(1): 26. [online] URL: http://www.ecologyandsociety.org/vol14/iss 1/art26/.

Huss, M., S. Usselmann, D. Farinotti, and A. Bauder. 2009. Glacier mass balance in the south-eastern Swiss Alps since 1900 and perspectives for the future. Erdkunde 64(2):119-140 http://dx.doi.org/10.3112/erdkunde.2010.02.02
Ingold, T. 2000. The perception of the environment: essays on livelihood, dwelling and skill. First edition. Routledge, New York, New York, USA and London, UK.

Irvin, R. A., and J. Stansbury. 2004. Citizen participation in decision making: is it worth the effort? Public Administration Review 64(1):55. http://dx.doi.org/10.1111/j.1540-6210.2004 .00346.x

Italian National Statistical Institute (Istat). 2006; 2009. Index. [online] URL: http://demo.istat.it/pop2009/index_e.html.

Johnson, C., E. Penning-Rowsell, and D. Parker. 2007. Natural and imposed injustices: the challenges in implementing 'fair' flood risk management policy in England. The Geographical Journal 173(4):374-390. http://dx.doi.org/10.1111/j.1475-49 $\underline{\text { 59.2007.00256.x }}$

La Provincia di Como. 2009-2010. La Provincia di Como. [online] URL: http://www.laprovinciadicomo.it/.

Lebel, L., T. Grothmann, and B. Siebenhuner. 2010. The role of social learning in adaptiveness: insights from water management . Environmental Agreements 10:333-353. http:// dx.doi.org/10.1007/s10784-010-9142-6

Lewicka, M. 2011. Place attachment: how far have we come in the last 40 years? Journal of Environmental Psychology 31 (3):207-230. http://dx.doi.org/10.1016/j.jenvp.2010.10.001

Lynch, D. R. 2010. Sustainable natural resource management. Cambridge University Press, Cambridge, UK. http://dx.doi.o rg/10.1017/CBO9780511816222

Mannarini, T., M. Roccato, A. Fedi, and A. Rovere. 2009. Six factors fostering protest: predicting participation in locally unwanted land use movements. Political Psychology 30:985918. http://dx.doi.org/10.1111/j.1467-9221.2009.00732.x

Manzo, L. C., and D. D. Perkins. 2006. Finding common ground: the importance of place attachment to community participation and planning. Journal of Planning Literature 20:335. http://dx.doi.org/10.1177/0885412205286160

Massarutto, A., A. de Carli, C. Longhi, and M. Scarpari. 2003. Public participation in river basin management planning in Italy: an unconventional marriage of top-down planning and corporative politics. Report of workpackage 4 of the HarmoniCOP project, Università degli Studi de Udine, Udine, Italy. [online] URL: http://www.harmonicop.uni-osnabrueck. de/_files/_down/Italy.pdf

McDaniels, T. L., R. S. Gregory, and D. Fields. 1999. Democratizing risk management: successful public involvement in local water management decisions. Risk Analysis 19(3):497-510. http://dx.doi.org/10.1111/j.1539-692 4.1999.tb00424.X

McLain, R. J., and R. G. Lee. 1996. Adaptive management: promises and pitfalls. Environmental Management 20(4):437448. http://dx.doi.org/10.1007/BF01474647 
Medema, W., B. S. McIntosh, and P. J. Jeffrey. 2008. From premise to practice: a critical assessment of integrated water resources management and adaptive management approaches in the water sector. Ecology and Society 13(2): 29. [online] URL: http://www.ecologyandsociety.org/vol13/iss2/art29/.

Milton, K. 2005. Meanings, feelings and human ecology. Pages ??? in K. Milton and M. Svasek, editors. Mixed emotions -Anthropological studies offeeling. Berg Publishers, Oxford, UK.

Mitchell, M. Y., J. E. Force, and M. S. Carroll. 1993. Forest places of the heart: incorporating social places into public management. Journal of Forestry 91(4):32-37.

Moisello, U., and F. Vullo. 2011. I massimi annuali di portata dell'Adda a Lecco in diversi regimi di deflusso. Publication No. 13. Consorzio dell'Adda, Milan, Italy.

Monti, S. 1900. Inondazioni del lago di Como dal 1431 al 1765 e provvedimenti per porvi riparo (Archivio di città). Volume 1900:128-172. Società storica Comense, Como, Italy.

Moran-Ellis, J., V. Alexander, A. Cronin, M. Dickenson, J. Fielding, J. Sleney, and H. Thomas. 2006. Triangulation and integration: processes, claims and implications. Qualitative Research 6(1):45-59. http://dx.doi.org/10.1177/14687941060 $\underline{58870}$

Nunes Correia, F., M. Fordham, M. da Graca Saaiva, and F. Bernardo. 1998. Flood hazard assessment and management: interface with the public. Water Resources Management 12:209-227. http://dx.doi.org/10.1023/A:1008092302962

Pahl-Wostl, C. 2007. The implications of complexity for integrated resources management. Environmental Modelling and Software 22(5):561-569. http://dx.doi.org/10.1016/j.envs oft.2005.12.024

Pahl-Wostl, C., J. Sendzimir, and P. Jeffrey. 2009. Resources management in transition. Ecology and Society 14(1):46. [online] URL: http://www.ecologyandsociety.org/vol14/iss1/ art46/.

Pahl-Wostl, C., J. Sendzimir, P. Jeffrey, J. Aerts, G. Berkamp, and K. Cross. 2007. Managing change toward adaptive water management through social learning. Ecology and Society 12 (2): 30. [online] URL: http://www.ecologyandsociety.org/vol12/ iss $2 / \operatorname{art} 30 /$.

Poggi, C., and C. Cantù, 2000. Como e le piene più famose del lago. Pfifferi Ed., E.P.I, Como, Italy.

Poletta, F., and J. M. Jasper. 2001. Collective identity and social movements. Annual Review of Sociology 27:283-305 http://dx.doi.org/10.1146/annurev.soc.27.1.283

Rydin, Y., and M. Pennington. 2000. Public participation and local environmental planning: the collective action problem and the potential of social capital. Local Environment 5 (2):153-169 http://dx.doi.org/10.1080/13549830050009328
Scannell, L., and R. Gifford. 2010. Defining place attachment: a tripartite organizing framework. Journal of Environmental Psychology 30(1):1-10. http://dx.doi.org/10.1016/j.jenvp.200 $\underline{9.09 .006}$

Selman, P., C. Carter, A. Lawrence, and C. Morgan. 2010. Reconnecting with a neglected river through imaginative engagement. Ecology and Society 15(3): 18. [online] URL: http://www.ecologyandsociety.org/vol15/iss3/art18/.

Stedman, R. C. 2002. Toward a social psychology of place: predicting behavior from place-based cognitions, attitude, and identity. Environment and Behavior 34(5):561-581. http://dx. doi.org/10.1177/0013916502034005001

Strang, V. 2004. The meaning of water. Berg Publishers, Oxford, UK.

Swanson, F. J., C. Goodrich, and K. D. Moore. 2008. Bridging boundaries: scientists, creative writers, and the long view of the forest. Frontiers in Ecology and the Environment 6 (9):499-504. http://dx.doi.org/10.1890/070076

Tompkins, E. L., and W. N. Adger. 2004. Does adaptive management of natural resources enhance resilience to climate change? Ecology and Society 9(2):10 [online] URL: http://w ww.ecologyandsociety.org/vol9/iss2/art10.

Toussaint, S. 2008. Kimberley friction: complex attachments to water-places in northern Australia, Oceania 78:46-61.

Tuan, Y.-F. 1977. Space and place: the perspective of experience. University of Minnesota Press, Minneapolis, Minnesota, USA.

Turati, P., and A. Gentile. 1858. Como ed il suo lago Illustrazione storica, geografica e poetica del Lario e circostanti paesi. Tipografia Giorgetti, Como, Italy.

Twigger-Ross, C. L., and D. Uzzell. 1996. Place and identity processes. Journal of Environmental Psychology, 16:205220. http://dx.doi.org/10.1006/jevp.1996.0017

United Nations. 1992. Rio Declaration on Environment and Development. United Nations Conference on Environment and Development, Rio de Janeiro, 3-14 June 1992. United Nations, New York, New York, USA.

Vis, M., F. Klijn, K. M. de Bruijn, and M. van Buuren. 2003. Resilience strategies for flood risk management in the Netherlands. International Journal of River Basin Management 1(1):33-40. http://dx.doi.org/10.1080/15715124 $\underline{.2003 .9635190}$

Webler, T., and S. P. Tuler. 2010. Getting the engineering right is not always enough: researching the human dimensions of the new energy technologies. Energy Policy 38(6) 2690-2691. http://dx.doi.org/10.1016/j.enpol.2010.01.007 
APPENDIX 1. Coding frame used to analyze textual items (letters and online comments)

\begin{tabular}{ll}
\hline \hline Category & Theme \\
\hline Emotion & Anger \\
& Sadness \\
& Surprise \\
& Shame \\
& Physical landscape, aesthetics \\
Relationship to place & Cultural/personal meaning of the lake and/or lakeshore \\
& Cultural/personal meaning of the city \\
Social & 'Us', Comaschi [Como residents] \\
& Collective support and efficacy of the protest \\
& Social continuity: reference to past and/or future generations \\
Accountability & Naming responsible people, calling for sanctions \\
Concerns with implementation process (political) & Legitimacy \\
& Economic implications \\
& Transparency of political process \\
& Critical awareness of lack of citizen's interest at the outset \\
Action & Stimulation \\
& Sharing of information \\
& Organization of events \\
\hline
\end{tabular}

Coding frame used to analyze textual items (letters and online comments) 
APPENDIX 2. Quotes extracted from textual data and translated into

English

1. In the presentation it was all-beautiful, the virtual pictures are still there, how beautiful! A shame they are only virtual (....) Please, give us the floods back and resign right away: I am one who voted for you. (Letter published on 25/09/09)

2. But, how could they do such a thing to the living heart of our beloved city (...)? I almost have tears in my eyes. (Letter published on 5/10/09)

3. My beautiful lake, to which I am very much attached, and to which I had even dedicated years ago a poem, in dialect to better express my deep feelings for it, cannot disappear this way (Letter published on 27/09/09)

4. No one can steal the lake... Leave us at least this little bit of nature that remains to be seen and admired! (Letter published on 25/09/09)

5. When I was a little boy on Saturday afternoons, my parents used to take me to the lakeshore to stroll and admire our lake. Then I grew up and I used to go with my friends, with my girlfriend. Now I am married, I went for so many walks there with my wife and each time we would stop on a bench to admire the lake! Now I have a child and I would like to be able to take her there, too, to admire the lake. Don't cancel the lake from us, please don't do it. It is beautiful to see it in the morning when I go to work and to greet it at night before going back home. It is part of my life. (Letter published on 30/09/09)

6. I have lived on milk and lake since my childhood that is since 75 years. I remember my dad who, every night after dinner, regardless of the weather and the season used to go out to the square to see his lake. When he came back, we used to ask him, for a joke: 'Dad, is the lake still there?'And his answer was: 'It is there and it is always more beautiful'. I think that now he would be turning in his grave. (Letter published on 1 Oct. 2009)

7. I would like for tomorrow's children to be able to stroll on the lakeshore with grandparents or parents, and stop enchanted throwing bread to the ducks and admiring the arrival of the swans, like we all did(...) I would like for the lake to remain everything it has been for us, grown-up Comaschi. (...) This wall prevents all of this! (Comment posted on 24/09/09, accessed on 14 Apr 2010)

8. How was it possible to design and build this horror? But those who have the power to govern are Italians? Or extraterrestrial aliens? (Letter published on $01 / 10 / 09)$

9. If the city lost the view of the Lario, it would lose itself (Letter published on 25 Sept. 2009)

10. Como cannot be apart from the lake. Como is 'the lake'. (Letter published on 05/10/09)

11. It's as if in Milan they decided to cover all the duomo and hide it from people's view...But are we joking? It's like taking off the soul of the city! (Letter published on 26/09/09)

12. The offense to the environment is the wall in construction. The lake, the lakeshore and the old town are a continuous whole: they are three inseparable realities in osmosis. The fracture caused by the wall breaks an equilibrium embedded in the culture of Como that lives serenely its panorama. (Architect, letter published on 30/09/09)

13. In Como fortunately, it is not so frequent to end up with the high waters, it is not necessary to 'secure' the city permanently, Como already has its walls, of another epoch, function and charm. (letter published on 02/10/09, [reference to the historical walls surrounding the old part of town])

14. Dismantlement of this wall of shame, which is useless! Almost surely we won't get any more floods, considering the climatic situation and the [lake levels managing body] (Letter published on 29/09/09)

15. Considering also that the flood events, as years go by, become less and less intense, maybe also because the gates in Lecco/Olginate are being better managed, I wonder in the end why this useless 'wall' has been built. (Letter published on 29/09/09)

16. How often has the lake been flooding? Every 3/4/5 years? And how much did it cost considering that everything is always covered by the insurances? (Letter published on 26/09/09)

17. Between walls, barriers and cement casts a go-go, now our lake has been caged and closed like a vulgar hydroelectric reservoir. (...) a project that has closed the lake but also the doors to all sensitivity and culture. (Letter published on 27/09/09)

18. The beauty and the romanticism of the lake on the square well surpassed the (few and well compensated) [flood] damage to the shore owners: besides, the flooding lake only took what was already its: Piazza Cavour used to be the port of Como, without walls, without roads, without benches, without barriers, without brigands, but with a splendid city at its back. (Letter published on 26/09/09)

19. I prefer a prospective week of lake flooding than a permanent cancellation of the landscape. (Comment posted on 24/09/09, accessed on 14/4/10)

20. There may be nothing left to do for us but cry by the wall, by our own wailing wall, trying to remember the glories of the past. (Letter published on 26/09/09)

21. But...I was born with the view to the lake and I will have to die in front of a wall but you are crazy?! (Letter published on 27/09/09)

22. (...) A disaster from the cultural and emotional perspectives for who really cares for the lake. I feel more pain than indignation. (Letter published on 
29/09/09)

23. Give us back the fabulous lakeshore of Como, which in difficult times like these, only with a little glimpse while driving past, brightens our mood! (Letter published on 26/09/09)

24. I am German and I have known the lake of Como for 20 years (...) To me and all of them [family and friends, from Italy and elsewhere] the lake has always had this strange effect: as soon as I arrive here I relax, I feel great, I breathe deeply and I forget the daily stress. This is due to a landscape of extraordinary beauty (Letter published on 4/10/09) 